\title{
Violence, Identity Mobilization and the Reimagining of Biafra
}

\author{
Ukoha Ukiwo*
}

\begin{abstract}
The events leading to the Nigeria Civil War marked the triumph of force and violence over dialogue and negotiation as a means of conflict resolution. The success of the Nigerian state in imposing a military solution on the preceding political crisis, and then suppressing the ensuing Biafran rebellion, has had a lasting effect on state-society relations. As a result, the state has not refrained from using violence at the slightest provocation against competing and conflicting ethno-religious groups. The tendency of the state to exercise domination through the deployment of violence implies an ongoing crisis of state hegemony rather than a resolution of civil unrest. This article argues that state violence was more important than ethnic divisions in triggering the secessionist attempt of Biafra, and has continued to create rather than resolve ethnic divisions across the country. The emergence in post-Civil War Nigeria of regimes that perpetrated or permitted mass violence against restive social groups remains critical to understanding the contemporary rise of ethno-nationalist movements and waning allegiance to the Nigerian state, particularly among the Igbo. The aim of the article is to underscore the understated salience of state violence in the debates on identity and citizenship in multi-ethnic societies.
\end{abstract}

\section{Résumé}

Les événements qui ont conduit à la guerre civile au Nigéria ont marqué le triomphe de la force et de la violence sur le dialogue et la négociation comme moyen de résolution des conflits. Le succès de l'État nigérian dans l'imposition d'une solution militaire à la précédente crise politique, puis dans la répression de la rébellion Biafra, a eu un effet durable sur les relations entre l'État et la société. En conséquence, l’État n’a pas renoncé à utiliser la violence contre les

* Department of Political and Administrative Studies, University of Port Harcourt, Port Harcourt, Nigeria. E-mail: uukiwo@hotmail.com. 
groupes ethno-religieux concurrents et conflictuels, à la moindre provocation. La tendance de l'État à exercer la domination par le déploiement de la violence implique une crise continue de l'hégémonie de l'État plutôt qu'une résolution de troubles civils. Cet article soutient que la violence d'Etat était plus importante que les divisions ethniques dans le déclenchement de la tentative de sécession du Biafra, et a continué à créer, plutôt que de résoudre, les divisions ethniques dans tout le pays. L'émergence dans le Nigeria de l'après-guerre civile de régimes qui ont perpétré ou autorisé la violence de masse contre des groupes sociaux agités demeure un facteur essentiel pour la compréhension de la montée contemporaine de mouvements nationalistes ethniques et du déclin de l'allégeance à l'État nigérian, en particulier chez les Igbo. L'objectif de cet article est de mettre en exergue l’importance sous-estimée de la violence d’État dans les débats sur l'identité et la citoyenneté dans les sociétés multiethniques.

\section{Introduction}

The ghosts of Biafra have wittingly or unwittingly been invoked in commentaries on contemporary manifestations of violence in Nigeria in three ways. Firstly, the bloody Nigeria Civil War is blamed for engendering a socio-political setting in which violence is normalized, embedding a 'culture of violence' in Nigerian society. By smashing the culture of peaceful conflict resolution, Biafra was said to have set in motion a process of militarization, in which violence is not only condoned but also celebrated and institutionalized as an instrument of statecraft. As Pius Okigbo puts it:

War time leads to a degradation of moral values. It upgrades patriotism, heroism, valour, but it degrades the moral code, excuses excesses of sadistic behavior, especially if these excesses are visited on the so-called enemy. Long after hostilities cease, it is often difficult to re-inculcate the normal moral code in the people. Nigeria has seen this experience which has debased public life and service (cited in Agbaje 2002:28).

The second way in which Biafra is implicated in contemporary violence in Nigeria is that it marked a watershed in the dissemination of small arms and light weapons among the populace (Hazen 2007). The war not only led to massive importation of arms and ammunition into the country but to the emergence and growth of a local arms industry, particularly in the southeast. Decommissioned soldiers and rebels retained some of the weapons for increasing engagement in criminal activities and inter-communal violence. The third way that Biafra is linked to contemporary violence in Nigeria relates to the vulnerability of African societies to becoming caught in a 'conflict 
trap'. Econometric studies conflicts in Africa by such scholars as Collier, Hoeffler and Rohner (2006:13) attempt to establish that:

(O)nce a country stumbled into a civil war, there was always the danger that it would enter a dysfunctional cycle in which the legacy of war was a heightened risk of further conflict, partly because of this time effect and partly because of the likely decline in income. The principal legacy of civil war is a grossly heightened risk of further civil war.

A common feature of these three explanations is that they suggest a causal connection between the Nigeria Civil War and contemporary violence. This article takes a different path by attempting to show that the Civil War did not set in motion the processes of contemporary violence in Nigeria, but that both are products of a prior causal factor. Both arose from the growing use of state violence as a tool of governance, a strategy that emerged from what Claude Ake called 'political anxiety'. In the face of weak institutions for managing political competition, 'political anxiety' refers to a 'fear of the consequences of not being in control of government associated with a profound distrust of political opponents', leading to antagonistic and increasingly violent relations between the state and oppositional political and social groups. This has transformed the state's 'legitimate monopoly of violence' from a mechanism for maintaining order into a form of oppression that undermines legitimacy and national cohesion. As a retired Nigerian general observed:

When the armed forces are called out for internal security role especially in ethnic riots or communal conflicts over issues that were created by politicians and should have been resolved politically, then you are asking for a military solution by running away from or buying time for a political solution. When this happens more and more, the institutional political control machinery and mechanism becomes weak. That is a sign of weak government and the room is created for the military and some civilian opportunists to believe that they can do better (Williams 2002: 100-1).

The main argument proposed here is that it was state violence, rather than cultural divisions, that triggered the secessionist attempt of Biafra and continues to foster ethnic nationalism in contemporary Nigeria. The Nigerian Civil War arose, not from ethnic antagonisms, but from botched efforts to restore Nigerian federalism. Prior to the war, the Igbo were the group with the strongest commitment to federalism, and the two coups that immediately preceded the Civil War represented attempts to reassert federalist principles amid growing ethnic wrangling and political crisis. However, suspicions of bias in the execution of the coups to serve ethnic interests exacerbated rather than calmed ethnic tensions. In the process, the coups gave way to 
ethnic pogroms carried out by Northern Nigerian civilians against fellow Nigerians of Igbo origin resident in the northern region of the country. The failure of the Nigerian security agencies to stop the pogroms of 1966-7 in which thousands of Eastern Nigerians were killed in several Northern Nigerian cities was perceived by many not as ethnic conflict, but as state violence. In failing to guarantee the security of law-abiding Eastern Nigerians, the army and other security agencies of the state became glorified 'ethnic militias' (Akinyemi 2002), and the state and its security apparatuses were perceived as jaundiced in the mediation of social conflicts. Deep-seated ethnic grievances were the product, rather than the cause, of this experience of state violence.

This is the forgotten lesson of the Nigerian Civil War. I suggest that state violence against various groups within society has led to the proliferation of ethnic and regional 'republics' within Nigeria, rather than vice versa, as generally supposed. The emergence in post-Civil War Nigeria of regimes that turned a blind eye to or appeared impotent amid killings of persons from particular ethnic or religious groups, and trigger-happy heads of state who gave shoot-on-sight orders to soldiers deployed to troubled sections of the country, remain critical to understanding the contemporary waning of the affective orientation of some Nigerians to the Nigerian state. The aim of the article is to underscore the understated salience of state violence in the debates on identity and citizenship in multi-ethnic societies. By state violence is meant any act by the state or its agents that causes physical or mental injury against the person or property of its law-abiding citizen or group of citizens. State violence also exists where the state or its agents may not have been directly responsible for the act but are perceived to have sanctioned the act by their failure to intervene or prosecute the perpetrators of violence.

If the raison d'être of the state is the security and prosperity of its members, the state that fails to protect the life, liberty and estate of its citizens loses the loyalty of those citizens. It is at this point, theoretically speaking, that such citizens transfer their loyalties to another entity that they trust to guarantee their collective security. Even in contexts where such citizens do not physically and or politically opt out of the state by secession, or a refusal to pay taxes or join the armed forces, withdrawal of allegiance is evident in the changing modes of self-identification and a reimagining of nationhood. I will argue that state violence explains why the Igbo ethnic group, which in the colonial era and during the early years of independence was apparently most committed to a common Nigerian identity, currently has the highest percentage of citizens who favour ethnic over national identity. The same destructive pressures of state violence that led to the outbreak of Civil War in the 1960s have triggered a reimagining of Biafra among the Igbo since the 1990s. 
In the next section I show that, contrary to the 'culture of violence' or 'conflict trap' theses, there was actually a reduction in the incidence of violence in the immediate post-war period. The image of Biafra faded in the context of state-supported efforts at reconciliation and the economic expansionism of the oil boom. The third section turns to an analysis of the factors that led to the return of state violence, generating increasing conflict between ethnic and religious groups and creating patterns of violence that tended to converge with particular force on the Igbo. A concluding fourth section presents the contemporary Igbo experience of state violence and demonstrates how this experience has fuelled a revival of self-determination and ethnic nationalism.

\section{The Absence of State Violence in the Immediate Post-Civil War Era}

Nigeria did not just survive the Civil War, it emerged from it a stronger state and a more united country. Three factors accounted for the new-found strength and unity. Firstly, the boom in oil exports and centralization of oil revenues enabled the Federal Government to be more visible in redistributive politics and invigorated centripetal tendencies in the Nigerian social formation. Secondly, the dissolution of Nigeria's three regions and creation of twelve smaller states, comparatively speaking, facilitated the devalorization of centrifugal forces and the containment of regionalism. It terminated the era when the regional tail wagged the federal dog. Thirdly, the Nigerian state became hegemonic in the sense that it was able to exercise domination without exertion of physical force and mobilization of violence. It is this third factor, which is contrary to the tenor of the 'war begets war' thesis, that this section addresses.

The absence of state violence in the immediate post-Civil War years ${ }^{1}$ stemmed from the recognition by the major dramatis personae of the central role of violence in the outbreak of conflict and of the necessity of nonviolence for conflict resolution and national integration. This recognition is well captured in the statements that both Ojukwu, the leader of Biafra, and Yakubu Gowon, the Nigerian Head of State, gave on 15 January 1970 to mark the end of the Civil War:

We are convinced that Biafra will survive. Biafra was born out of the blood of innocents slaughtered in Nigeria during the pogroms of 1966. Biafra will ever live, not as a dream but as the crystallization of the cherished hopes of people who see in the establishment of this territory a last hope for peace and security. Biafra cannot be destroyed by mere force of arms. ... Biafra lives (Ojukwu in Kirk-Greene 1993: 456).

The so-called 'Rising Sun of Biafra' is set for ever. It will be a great disservice for anyone to continue to use the word Biafra to refer to any part of the East 
Central State of Nigeria. The tragic chapter of violence is just ended. We are set at the dawn of national reconciliation. Once again, we have an opportunity to build a new nation (Gowon, in Kirk-Greene 1993:897).

There is a sense in which Gowon had anticipated Ojukwu by recognizing that Biafra could not be destroyed by mere force of arms. This is evident in the code of conduct he handed down to his soldiers. Putting aside for a moment the controversies surrounding what actually transpired or did not happen in the battlefield, Gowon was consistent in his call for an economical use of violence in the war. He recognized that the appeal and staying power of Ojukwu and his advisers derived from the memories of violence against Igbo and Easterners, which the Biafran leadership masterfully manipulated. Gowon deemed the economy of violence not only important for winning the war but also for winning the peace. He told his soldiers:

You must all bear in mind at all times that other nations in Africa and the rest of the world are looking at us to see how well we can perform this task which the nation demands of us. You must also remember that you are not fighting a war with a foreign enemy. Nor are you fighting a religious war or Jihad. You are only subduing the rebellion of Lt. Col. Odumegwu-Ojukwu and his clique. You must not do anything that will endanger the future unity of the country. We are in honour bound to observe the rules of the Geneva Convention: (Gowon, in Kirk-Greene 1993:456; emphasis added).

It is difficult to ascertain under the conditions of warfare whether Gowon kept his word or whether the soldiers dutifully obeyed his orders. There were reports of air strikes on hospitals and markets in contravention of the Geneva Convention. However, the fact that many Nigerian soldiers not only allowed cross-border trade but also married Biafran women suggests that they agreed with their commander-in-chief that this was not a total war. In fact, a rare gender analysis of the Civil War that documents such liaisons also highlights the role of the controversial marriages in both providing succour to starving Biafran families and facilitating post-war reconciliation and reintegration (Chuku 1982).

In retrospect, it seems that the policy of economic blockade was partly aimed at reducing the death toll from direct combat. For instance, Gowon justified the decision of his government to ban a number of foreign governments and humanitarian organizations from participating in the distribution of supplies after the war on the ground that they provided relief materials to cushion the effects of the economic blockade:

These are the governments and organizations which sustained the rebellion. They are thus guilty of the blood of thousands who perished because of the prolongation of the futile rebel resistance. They did not act out of love for 
humanity. Their purpose was to disintegrate Nigeria and Africa and impose their will on us ... we shall therefore not allow them to divide and estrange us again from one another with their dubious and insulting gifts and their false humanitarianism- (cited in Streamlau 1977:368).

The commitment of the Federal Government towards non-violence became incontrovertible after the Civil War. Although the government failed to compel people who had occupied so-called abandoned property in Lagos, Kaduna, Enugu, Port Harcourt and Aba among other towns to restore them to their rightful owners, it generally succeeded in creating an atmosphere in which there were no violent recriminations. The non-violent end to the Nigerian Civil War confounded Western observers. For instance, the French journalist de Jorre, who was astounded that 'there was no genocide, massacres or gratuitous killings', remarked that 'in the history of warfare, there can rarely have been such a bloodless end and such a merciful aftermath' (cited in Stremlau 1977:366). Contrary to perceptions that the war created a situation in which Nigerians began to celebrate violence, the Gowon administration gave a strong symbolic signpost to the policy of 'no victor, no vanquished'. There were no victory celebrations; no triumphal parades; no war monuments or memorials; no battle honors; and no promotion for service in battle (Streamlau 1977:371).

Moreover, the resistance movement completely demobilized and guerrilla activity did not follow after the war even though many erstwhile Nigerian soldiers and policemen who joined the armed forces of defunct Biafra were not readmitted or retired with benefits. This is because the state had guaranteed the security of Igbo people who soon after the war decided to return to major Nigerian cities in search of jobs and business opportunities. Although the returnees suffered great losses from the poor exchange value of the Biafran currency, which ceased to be legal tender after the end of the war, they felt safe enough to embark on new ventures. Nothing demonstrates the reintegration of the Igbo into Nigerian socio-political and economic life as clearly as the post-war careers of some of the major officers of the defunct Biafran government. Streamlau (1977:372), who gives a snapshot of their careers, shows for instance that Dr Pius Okigbo, Ojukwu's adviser, established a consultancy firm in Lagos and won contracts from the Federal Government while Comrade Uche Chukwumerije, erstwhile director of propaganda in Biafra, became a magazine publisher and was part of the press delegation that accompanied General Gowon to OAU meetings. The attempts at reintegration and the healing process that took place in the 1970s were 'exemplary by global standards' (Gboyega 1997:150).

The process of reintegration took place in an environment of economic boom, relative security and a general sense among prominent members of 
the regime that the destiny of Africans at home and in the diaspora rested on developments in Nigeria. Although the oil boom generated social inequalities and resulted in increased crime rates, violence was mostly inter-personal. There were no reports of inter-group violence and state violence was notable in its rarity. Gowon's conciliatory and accommodating traits were eventually blamed for making government appear weak and unlike a military regime. This, it was argued, created a salubrious environment for indiscipline and corruption among public officers. When Gowon reneged on the collective decision of the regime to hand over power to civilians in 1974, he handed some elements in the regime a popular reason to effect a change of leadership. On 29 May 1975, Yakubu Gowon was toppled while attending a meeting of the Organization of African Unity (OAU).

Against the background of the rarity of political violence during this period, it is not surprising that this was Nigeria's first bloodless coup. However, the attempt of the new regime under Gen. Murtala Mohammed to sanitize the Nigerian polity through summary dismissal of public officials accused of corrupt practices, and sacking of officials considered to be too close to the former head of state, generated political tensions across the country even though some of the purges were welcomed by the Nigerian public. Moreover, the plan of the regime to create new states and local governments led to the resurgence of ethno-communal mobilizations and political anxiety. Ten days after his regime created seven new states, Mohammed was assassinated in an unsuccessful coup on 13 February 1976.

\section{Political Anxiety and the Return of State Violence}

The assassination of Murtala Mohammed and its aftermath launched Nigeria into another era of political anxiety and state violence. The mutineers, who included close relatives of the former head of state, were mostly from the Middle Belt and were allegedly aggrieved that Middle Belt indigenes had been relegated to the background in the new regime. They felt this was an unjust reward for their contribution to the Civil War effort. This was the first indication of an emergent martial right to rule, the trend where Nigerian generals based their claims to rulership on their prowess in fighting to keep Nigeria together during the Civil War. The summary execution of the 32 officers involved in the coup attempt, including a general, found guilty by the special military tribunal on 15 May 1976, revived memories of the events of 1966 where political violence led to the elimination of a generation of politicians and military officers from a particular region of the country.

The effects of the failed coup on Nigerian political culture were profound. Firstly, since Gen. Mohammed was killed while going to work without a convoy, security around the head of state and other senior regime officials 
was increased. This marked the beginning of a new era where the appurtenances of office included sirens and convoys intended to protect the governors from the governed. Secondly, the ensuing political anxiety made the regime intolerant of criticism and opposition from groups both within the regime and in civil society. The first group to attract the ire of the regime was musicians. In 1977, soldiers invaded 'Kalakuta Republic', the commune of Fela Anikulapo Kuti, the Afrobeat artist, for releasing an album entitled 'Zombie', which was a scathing critique of praetorian rule in Nigeria. Several residents, including the artist's mother, a nationalist and women's rights activist, were wounded in the incident. The next group to become victims of state violence was students.-In April 1978, the government deployed soldiers to quell student demonstrations against an increase in food costs in the universities. The confrontation between soldiers and students resulted in the death of some students and the closure of universities. Universities readily became sites of struggle as the military authorities assumed greater powers over the appointment and promotion of principal staff. Vice chancellors and lecturers were sacked and others appointed with immediate effect through radio announcements.

State violence coincided with rising agitations for return to democratic rule. The military government of Gen. Olusegun Obasanjo continued with the transition programme initiated under Mohammed's short-lived tenure and established a Constituent Assembly, which was to consider a draft constitution prepared by the Constitution Drafting Committee. One of the most divisive issues in the Assembly was the proposal for the establishment of a Federal Sharia Court of Appeal. The walkout staged by Northern delegates proved costly as the Assembly, with a Southern and Middle Belt majority, recommended a constitution that did not provide for a Federal Sharia Court. The popular perception that this was a victory for Christians generated resentment among Muslims, setting the stage for future religious conflicts.

Religious conflicts assumed violent dimensions in the Second Republic inaugurated on 1 October 1979. There were, on the one hand, more incidents of sectarian violence between Islamic sects and, on the other, confrontations between Christian and Muslims in several cities in the North. For instance, between 1980 and 1985, there were confrontations between security agents and the Maitatsine sect, which criticized the practices and teachings of orthodox Islamic sects, resulting in the loss of some 10,000 lives. More lives were lost in October 1982 when riots that started with objections of Muslims to the reconstruction of church close to a mosque in Kano, spread to Zaria and Kaduna. Although these conflicts were about struggles for preeminence among adherents of religious groups, they also had political and economic undertones (see Osaghae 1998; Williams 1997). A high point of this period 
was the increasing reliance of the civilian administration, which faced a legitimacy crisis from the onset as a result of controversies over the general elections, on the use of force to manage dissent. For instance, on 28 April 1980 , the government deployed police to quell peasant protests against the construction of a dam in Bakolori, Sokoto State. The government claimed that 25 persons were killed, though unofficial sources indicated that there were 386 casualties and 216 bodies were physically identified (Shettima 1997:76).

The regime's increasing reliance on force was evident in the creation of a special riot mobile police unit to suppress dissent. The size of the police force grew tenfold from 10,000 to 100,000 between 1979 and 1983. Arms expenditure also skyrocketed from 3 million to 36 million between 1979 and 1982 (Osaghae 1998). The period also witnessed the proliferation of vigilante groups and hit squads attached to powerful politicians. These groups were implicated in the violence that marred the controversial 1983 general elections.

The military cited electoral fraud, state violence, allegations of corruption and abuse of office by politicians as the reasons why they intervened again on 31 December 1983. However, the new regime bungled the popular goodwill that greeted its arrival by unleashing a reign of terror on civil society in its attempt to fight indiscipline. The media, professional organizations such as the Nigerian Medical Association (NMA) and the Nigerian Bar Association (NBA), as well as 'politicians' were victimized, and soldiers brutalized ordinary citizens in the name of instilling discipline. State violence was fuelled by two factors during this period. Firstly, the regime used violence to create an 'enabling environment' for its unpopular economic recovery programme. Secondly, the regime deployed violence to enervate countervailing social forces. The latter was necessary because, led by two Muslims and Northerners, the new regime was the first to ignore the country's postindependence convention in which religious and regional factors were crucial in the filling the two topmost positions. The fact that Generals Muhammadu Buhari and Tunde Idiagbon preferred rule by force to rule by dialogue and consensus was adduced as one of the reasons for the palace coup that swept them out of office in August 1985.

It is against this background that the regime of General Ibrahim Babangida started out as a liberal military government that was sensitive to public opinion and advertised its preference to govern by consensus. However, once the regime came under pressure it became apparent that consultative mechanisms were rituals of regime legitimatization. Early in its life, the regime went against the recommendations of the nationwide debate on the controversial IMF loan and the Political Bureau. It also ignored widespread appeals for clemency and proceeded to execute 14 military officers convicted of plotting a coup. 
The fact that eight of the 14 condemned officers were from Benue State and the ringleader, General Mamman Vatsa, was Babangida's best man was intended to show that the regime would not be swayed by sentiment when it faced any threat to its survival. The remaining veneer of regime openness was eroded when the second in command and highest-ranking Christian in the regime claimed that the controversial enrolment of the country into the Organization of The Islamic Confrence (OIC) was never discussed in the Supreme Military Council.

In the context of rising religious fundamentalism in the country, the OIC issue triggered several incidents of violent religious conflicts in Northern Nigerian cities that were quelled by the deployment of soldiers. Soldiers were also used to silence students' protests against the introduction of structural adjustment and deteriorating living conditions. University lecturers, unionized workers, journalists and lawyers soon joined the category of 'extremists' that the regime sought to suppress or eliminate. By the end of the 1980s, the Nigerian public had become traumatized by state violence as the increasingly unpopular Babangida regime seemed to have emptied its bag of tricks for hanging on to power. The militarization of Nigerian society became disconcerting even to 'experts of violence' like the former Biafran leader:

The pervasive violence of Nigeria is underlined and highlighted by the sight of uniforms everywhere. ... Uniforms abound and a citizen of this country is permanently intimidated by this proliferation of uniforms - some he recognizes and respects; others he does not recognize but dares not disrespect. Everywhere the citizen of this country is assaulted with violence: in his home where he is obliged to erect and inhabit his own prison; in his place of work which he has to turn into a fortress and in the streets where his fears borders on schizophrenia.... With mouth agape, ‘the Nigerian' has watched a national metamorphosis where 'keeping the peace' has become 'killing the peace' (Ojukwu 1989:26).

The 1990s, however, witnessed more state violence as the military regime manoeuvred to remain in power against public opinion and in contradiction to its own transition programme. The military dictatorship fostered ethnic, religious and regional polarization in the country that manifested in various violent inter-group conflicts. The fact that these identity conflicts and struggles were not confined to society in general but had also infiltrated the military institution was evidenced by the increasingly regional and ethnic character of a series of coup plots. In April 1990, the regime foiled an attempt to overthrow it by violent means. Described as the bloodiest coup in the country's history, the 22 April coup was hatched and executed by officers largely from the Niger Delta. The regional motivation of the coup plotters is evidenced by their decision to excise the 'core' Northern states from Nigeria, 
and by the alleged involvement of civilians in the planning and execution of the botched plot. Out of 100 military and civilians charged 67 were executed, and the regime felt so vulnerable in the aftermath of the coup that it hurriedly relocated to Abuja (Osaghae 1998).

Since challenges to the regime increasingly took ethno-regional forms, as the state had assiduously worked towards crippling and compromising other civil platforms, state violence was increasingly perceived as directed at ethnic and regional groups. This was manifested in the failure of the regime to curb recurrent religious conflicts in northern cities where Easterners, mostly Igbo, were the cannon fodder. In 1993, the regime annulled the 12 June presidential elections, adjudged as free and fair by both domestic and foreign observers. The annulment deepened the political crisis as it lent credence to perceptions that the so-called 'Northern oligarchy' was determined to hold on to power at all cost. Popular resistance to the annulment, which received tacit support from the military hierarchy, forced Gen. Ibrahim Babangida to 'step aside' and leave behind an Interim National Government (ING) of dubious legitimacy (see Alli 2001).

However, Nigeria was thrown from the frying pan into the fire when General Sani Abacha, the Minister of Defence, sacked the ING and returned the country to full-blown military rule to defend the annulment. He arrested and detained Alhaji MKO Abiola, winner of the 12 June-elections, after the latter declared himself president. Anxious to remain in power, Abacha unleashed violence at both real and imagined opponents. The strategy to eliminate all opposition ranged from assassination of members of the National Democratic Coalition (NADECO), the rallying point of groups seeking restoration of the 12 June mandate; closure of critical media houses; proscription of labour unions; indefinite closure of universities; to liquidation of businesses of political opponents. Victims of the regime included Kudirat Abiola, wife of the jailed winner of the historic elections, and Alfred Rewane, a NADECO financier, both of whom were murdered in cold blood. Alex Ibru, publisher of the Guardian newspapers, narrowly escaped being killed because he failed to restrain his newspaper, though he had been appointed Minister of Internal Affairs by the regime. Critical generals such as Olusegun Obasanjo and Shehu Musa Yar'Adua were also arrested, convicted and jailed for plotting to overthrow the regime. A sense that Abacha was afraid of his own shadow became apparent when his second in command, General Oladipo Diya, was also arrested, convicted and jailed for plotting a coup. Most of the named conspirators, in what most Nigerians perceived as one of Abacha's phantom coups, were Yoruba.

The Yoruba became the butt of state violence because protests against the annulment were loudest in the south-west though most Nigerians rejected 
the annulment. In fact, the military regime succeeded in ethnicizing the 12 June struggle and making it appear as though it was a Yoruba affair. The onslaught against the Yoruba led to the emergence of the Odua Peoples' Congress (OPC), an ethno-political association committed to defending the Yoruba 'race'. OPC members became enmeshed in conflicts with state security agencies and other ethnic groups that they perceived were either in support of the annulment or not committed to the struggles against the military.

But it was not just the Yoruba who were singled out for punishment. Increasingly, minorities in the Niger Delta, protesting against environmental degradation and exploitation by the unholy alliance between oil capital and the Nigerian state, became victims of a specific genre of state violence called 'petro-violence' (Watts 1999; Zalik 2004). The ‘tiny’ Ogoni group was isolated and made an example of, to teach other groups that the Nigerian state was still capable of suppressing rebellion. Ken Saro-Wiwa and other members of the Movement for the Survival of Ogoni People (MOSOP) were hanged, after scores of Ogoni women were raped and hundreds of Ogoni youth were murdered by Nigerian soldiers (see Ibeanu and Luckham 2006).

To be sure, violence was not the only weapon that the brutal military regimes used to keep their illegitimate power. The military wooed the venal political class with appointments, and state and local government-creation exercises. However, such bribes often resulted in factional conflicts and violent inter-group conflicts. For instance, state and local government-creation exercises triggered conflicts between the Ife and Modakeke in Osun State; Ijaw, Urhobo and Itsekiri in Delta State; Umuleri and Aguleri in Anambra State; Jukun, Tiv and Chamba in Taraba State; and 'Hausa-Fulani' and other 'indigenous' groups in Bauchi and Plateau States. The appointment of Uche Chukwumerije, erstwhile Biafran propaganda chief, as Abacha's information minister became a sore point in Igbo-Yoruba relations. In most of these conflicts, the state was perceived as partisan. Security agents deployed to restore peace were accused of supporting one group against the other. It is hardly surprising therefore that several communities regarded the Nigerian military forces as an ‘army of occupation' (Ukiwo 2003; Hazen 2007). Such communities increasingly resorted to establishing or reviving ethnic militias and vigilante groups as they believed the state had become a predator instead of a protector.

The 'miraculous' demise of Abacha in 1998 and the subsequent transition to civilian rule in 1999 did little to change the character of the Nigerian state. Like his military predecessors, the government of Chief Olusegun Obasanjo was fatally afflicted by the virus of political anxiety. The strenuous effort of the guest president to become de facto party leader and father of the nation 
destabilized the ruling party and the polity. Also destabilizing for the polity was the widespread perception that the 'power-shift' to the South West was influenced by the militant agitations of the OPC. It is hardly surprising that other 'oppressed' groups in the Niger Delta, Middle Belt and South East activated militias and self-determination movements in the post-military period to agitate for greater power at the centre. These 'subaltern' groups, however, were taught the Orwellian lesson that while all ethno-regional groups are equal some groups are more equal than the others in the discriminatory response of the regime to agitation. A newspaper columnist captured widespread perceptions of selective state violence in the following words:

Each time there is a report of anarchy in the South-west, the man in Odi, Bayelsa State in the South-south zone surely expects to hear that a battalion of soldiers have been deployed there to restore peace. Already, a precedent has been set. For harbouring bandits, Odi town was pounced on last November by a battalion of troops of the Nigerian Army, leaving tales of sorrow, tears and blood. So, with its increasing nuisance, OPC is today putting Obasanjo in a position of having to explain to the Odi man why these instances of barefaced outlawry have not been treated with the savage response similar to what happened in Odi last year (Odion 2000).

Despite the national outrage against the Odi Massacre, the regime also deployed soldiers to destroy Zaki Ibiam, another 'minority' community in Benue State, that allegedly harboured people who had killed soldiers. Yet the same regime looked helplessly to the judiciary to resolve the Sharia crisis that precipitated the massacre of tens of thousands of Nigerians mostly from the South and Middle Belt in religious rioting in several Northern cities. The regime also declared a state of emergency in Plateau State over the failure of the state government to curb communal violence, even though similar forms of violence were raging in other Northern states at the time.

It is this perception that the state had been captured and had become a machine of violence to serve particular interest groups, as well as the perception that power flows from violent agitation, that is responsible for the recent revival of self-determination movements in Nigeria. I demonstrate this with the case of contemporary ethnic mobilization among the Igbo in southeastern Nigeria.

\section{State Violence and the Resurgence of Biafra}

The rising sun of Biafra had set by 1982 when Ojukwu returned to the country at the end of his 'short' trip in search of 'peace', which turned out to be a 13-year exile in Côte d'Ivoire. The crowds that gathered to welcome him evinced the changed circumstance with the form of greetings they accorded their quondam hero. As sounds of 'Onyeije Nno' ('Welcome, traveller') and 
not 'Nzogbu Nzogbu, Enyimba Enyi' (an Igbo war chant) rent the air in Aba, Onitsha, Owerri and Enugu, it was evident that the crowds had gathered to welcome a 'traveller' instead of an ethnic hero. Ojukwu himself seemed to have abandoned his ambitions of leading the Igbo people to freedom when he accepted the title of 'Ikemba' from his native Nnewi. The only befitting title given to the erstwhile governor of Eastern Nigeria, and self-proclaimed leader and defender of the Igbo people, was an honorary title from his clan. Ojukwu's decision to join the ruling National Party of Nigeria (NPN) in appreciation of the presidential pardon extended to him and to contest a senatorial seat on the platform of the party that was widely regarded as the bastion of 'Hausa-Fulani hegemony' (from which Biafra was supposed to free the Igbo), epitomized the eclipse of Biafra.

Ironically, in 1969 and 1970, Dr Nnamdi Azikiwe had taken up the task of taking the Igbo back to mainstream Nigeria through his missives from Lagos, which proclaimed that Nigeria was 'safe' for returning Igbo. ${ }^{2}$ In 1983, it was Ojukwu's turn to lead the Igbo back into the mainstream of Nigerian politics, from which Azikiwe's Nigeria Peoples Party (NPP) seemed to have sequestered them. Zik the nationalist was leading a party that by 1983 was barely struggling to survive in the Igbo heartland, while Ojukwu the 'rebel' was wooing his people back to the political centre. Ojukwu lost the senatorial elections in 1983. This political disgrace was only mitigated by the military intervention, which did not allow his little-known opponent to savour electoral victory.

Twenty years later, in 2003, Ojukwu's second appearance in partisan politics was as the presidential candidate of the All Progressive Grand Alliance (APGA), a party that was hoping to reap benefits from the clamour for an Igbo president. By 2003, Ojukwu had been elevated from 'Ikemba Nnewi' (Strength of Nnewi) to 'Eze Ndi Igbo Gburu Gburu' (King of the entire Igbo nation) - an invented 'traditional' title in defiance of the well-known Igbo parable that 'Igbo enwe(ghi) eze' (The Igbo do not have kings). He had also discarded the trite honorary title of 'Chief' for 'Dim' (Warrior).

How do we explain the re-radicalization of Ojukwu? What transpired between 1983 and 2003 to make Ojukwu reconsider reclaiming his 'destiny' as leader of the Igbo? The answer lies in the Igbo experience of violence during this period in the many ethno-religious riots in Northern Nigerian cities. The particular event that re-radicalized Ojukwu was the bloody Kano riots of 1991. Ojukwu, who toured Kano at the invitation of Igbo communal associations in the city, claimed he was dazed by the extent of suffering of his people. Ojukwu reportedly said he was ready to fight again to protect his people. He declared that 'if the sacrifice needed for the building of the Nigerian nation is the constant shedding of Igbo blood, then let us not be a nation'. 
Although nine years were to elapse before the rise of the Movement for the Actualization of the Sovereign State of Biafra (MASSOB), Ojukwu's declaration signalled the rebirth of Biafra. He was responding to the feelings of victimhood among the Igbo, especially the youth. Several events since the mid-1980s had created a persecution complex among the Igbo. Firstly, Commodore Ebitu Ukiwe, the first Igbo to be appointed second in command under a military regime, was allegedly removed from office over his opposition to the surreptitious enrolment of Nigeria into the OIC (Osaghae 1998). Secondly, Igbo residents in some Northern Nigerian cities had become easy targets in incessant religious riots. Thirdly, the Igbo were perceived as having lost their stature as one of the country's majority ethnic groups. Minoritization of the Igbo stemmed from political marginalization as Igbo elites became increasingly scarce in Federal executives and Supreme Military Councils, being only considered fit for 'non-juicy' positions (Mustapha 2006). Fourthly, the Igbo were perceived to have lost out in successive state and local government-creation exercises. Whereas there are six states each in the South West, South South, North East and North Central, and seven states in the North West, the Igbo only have five states, with dire implications for their share of the national cake. Fifthly, there were allegations that the Igbo had been neglected in the distribution of Federal projects and Federal services. This absence of Federal presence was epitomized by the absence of security in Onitsha and Aba, both thriving Igbo commercial cities. The poorly equipped and unmotivated Nigeria Police Force could not withstand the surging wave of armed robbery and banditry that had enveloped the cities and posed a threat to commercial activity, which in the absence of jobs in the public sector became a means of social mobility among young Igbo men. Igbo traders rose to the occasion to establish vigilante groups to protect their businesses. However, this initiative became a victim of high-wire politics between some governors of the Igbo states and the Federal Government (Ukiwo 2003a; Meagher 2007).

Meanwhile, the Igbo elite were perceived as patently incapable of forging a common front to address the 'threats' and 'challenges' facing the Igbo people in contemporary Nigeria. ${ }^{3}$ Some effort at unity was made when elite figures formed Ohanaeze Ndi Igbo, which became the dominant pan-Igbo organization by 2000 and was popular for documenting and presenting human rights violations perpetrated against the Igbo between 1966 and 1999 to the Human Rights Violations Investigation Commission. However, the group was soon fractionalized by internal power tussles and party politics. The Ohanaeze began to fall apart in 2003 as the general elections approached. The bone of contention was whether or not the body should make good its 
agitation for an Igbo presidency by supporting an Igbo candidate and sponsoring a political party. Ohanaeze was divided over whether the Igbo should support former Vice President Alex Ekwueme, who was aspiring for the ticket of the ruling Peoples Democratic Party (PDP), or OdumegwuOjukwu, who had secured the APGA ticket unopposed, or wait for the 'turn of the Igbo' in 2007. The PDP governors of the Igbo states managed to reunite the group after the 2003 elections. However, the ambition of four out of five Igbo state governors to become the 'Igbo president' in 2007 was an indication that the crisis had merely been postponed. It is hardly surprising that Ohaneze split on the eve of the 2007 general elections over the desire of some members to endorse Dr Orji Uzor Kalu, Governor of Abia State, as the 'consensus' Igbo candidate for the presidency. The populist governor had become the beacon of hope of Igbo youth through deft manipulation of antiObasanjo sentiments in Igboland, arising partly from the inability of the Federal Government to protect Igbo life and property (Igwe and Awoyinfa 2001).

Igbo youths have rallied around MASSOB and other groups such as the Biafra Foundation and the Biafra Actualization Forum, mainly based in the United States, all of which agitate for the reestablishment of the Biafra State. The direct role of violence in instigating ethnic nationalism and selfdetermination movements is evidenced by the emergence of MASSOB in the crucible of the Sharia riots of 2000 in which about 5,000 Igbo residents in a number of Northern Nigerian cities were killed (Agbu 2004:27). Though born out of violence, MASSOB has eschewed all acts of political violence, preferring to realize its objectives through peaceful means. This method is attributed to the ideology of its founder and president, Chief Ralph Uwazurike, who studied in an Indian university and was influenced by Gandhi's philosophy of non-violence (Omeje 2005:631).

Thus, MASSOB and its sister-organizations have embarked on the acquisition of most of the appurtenances of a sovereign state, except a national army. It has launched and hoisted the Biafra flag in several Nigerian cities and villages; declared 30 May, the date of the outbreak of the Nigeria Civil War, as 'Biafra Day' when all 'Biafrans' are supposed to stay at home; purportedly reproduced the Biafran currency; opened and run a radio station; established an embassy in the capital of the world's superpower, the United States; and mobilized 'Biafrans' against participating in such civic duties as elections and the census in Nigeria. Most importantly, MASSOB has embarked on grassroots mobilization, tapping on the resentment of jobless and aggrieved youths to establish branches of the organization in many Igbo cities and towns. Not surprisingly, these provocative acts have drawn the ire of the Nigerian State, which has responded by arresting MASSOB leaders and burning 
their operational bases. This response of the state has unwittingly boosted support for MASSOB as its supporters complain that the state has used excessive violence to clamp down on a dovish organization whereas other organizations and ethnic militias that have adopted violent tactics, such as the OPC, have been treated with kid gloves (see Ukiwo 2003b).

As the popularity of MASSOB surged, it nonetheless remained disconnected from the dominant power blocs in the region. Although Ojukwu expressed symbolic support for the organization by participating in the opening of Biafra House in Washington DC and declaring that he was ready to fight again to protect the Igbo, the relations of the organization with most Igbo elites is at best lukewarm, and at worst actively hostile. Most of the governors of the Igbo states in the Fourth Republic regarded MASSOB members as irritants and undesirable elements (see Egwuonwu 2004). For instance, following clashes between MASSOB and road transport workers in 2006, Peter Obi, the Anambra State Governor, appealed to the Federal Government to deploy soldiers to rid the state of MASSOB activists and other miscreants. ${ }^{4}$ The Governor alleged that MASSOB was being sponsored by certain political interest groups to destabilize the state government. ${ }^{5}$

Further evidence of this lack of support is the fact that the Igbo political establishment did not embark on a campaign for the release of Uwazuruike and many of his lieutenants after they were arrested for treason in a general clampdown on leaders of ethnic militias in 2005. This contrasted sharply with mobilizations among the Yoruba and Ijaw political establishments for the release of Ganiyu Adams of the OPC and Alhaji Mujahid Asari Dokubo of the Niger Delta Peoples Volunteer Force (NDPVF). It was not until the continued incarceration of Uwazuruike several months after other leaders of ethnic militias had been released sufficiently embarrassed the Igbo political establishment that some Igbo senators began to demand Uwazuruike's release to enable him to perform the funeral of his late mother. Uwazuruike was given leave from detention in late October 2007 after several Nigerian newspaper editorials had joined the campaign for his release. However, the Uwazuruike saga again portrayed the Nigerian State as biased and lent credence to perceptions that the Igbo were being treated as second-class citizens. As the MASSOB leader said in the reception organized in his honour:

Now, I have not been granted bail. I have only been allowed 90 days to go and bury my mother. I, therefore stand to reason that if my mother had not died, I will certainly not have been released. Asari Dokubo's mother did not die before he was released. Ganiyu Adams' mother did not die before he was released. Frederick Fasehun's mother did not die before he was released. My mother had to die before I was released simply because I am an Igbo man. ${ }^{6}$ 
As a result of the travails of the organization and its leaders, ${ }^{7}$ MASSOB has become more popular among Igbo people. For instance, judging by the attendance at the reception organized for Uwazuruike in Enugu, the Vanguard newspaper reported that 'it has become clear that over 90 per cent of the entire Igbo people are, indeed, backing the movement' ${ }^{8}$ This popularity rating is better appreciated if juxtaposed with results of AFROBAROMETER surveys conducted in 2007, which showed that the Igbo had the greatest percentage of respondents who preferred their ethnic identity to their national identity. While the respondents from other major ethnic groups who preferred ethnic to national identity was 29 and 22 per cent respectively for Yoruba and Hausa, it was 53 per cent among Igbo respondents. The other ethnic group that exceeded the national average of 31 per cent was the Ijaw at 45 per cent (Lewis 2007). This is striking, considering that the Igbo were the most committed Federalists in the period just before the Civil War.

\section{Conclusion: Violence, Identity Mobilization and the Reimagining of Biafra}

The post-1980 Igbo experience of violence discussed above led to the proliferation of memoirs and novels about the Civil War, first by war veterans and later on by younger elements who recalled childhood war experiences or retold tales of suffering and slaughter (see, for instance, Madiebo 1981; Okocha 1994; Adichie 2007). ${ }^{9}$ Although the authors of these books and monographs often claimed their objective was not to reopen old wounds, representation of gory accounts of violence against the Igbo, the pre-war pogrom, wartime air strikes and starvation techniques, and post-war abandoned property saga, cumulatively reawakened a persecution complex among the Igbo. For instance, following the Sharia riots of 2000 and 2001, the Igbo Youth Movement (IYM), a group that was agitating for the Igbo presidency, sponsored the republication of the report of the tribunal established by the then Government of the Eastern Region to probe the pogroms of 1966 and 1967 (Obumselu 2001). The report, which showed that 37,000 Easterners (mostly Igbo) had been killed in 1966, worked to situate contemporary experience of violence in historical perspective. The impact of the reprint and similar memoirs of violence was not just to expose the scale of violence to which the Igbo had historically been subjected but also that they drew attention to the 'traditional' unwillingness of the Nigerian State to protect Igbo life and property.

The current experience of state violence encourages the excavation of collective memories of violence before and during the Civil War, while bracketing the period of reconciliation after the war. As in 1966, perceptions 
of state complicity in physical and mental violence against the Igbo have fostered identity mobilization and the evolution of communal self-defence mechanisms. In the context of growing violence against Igbos in religious riots in Northern Nigeria, vigilante groups in Igbo towns have begun to embark on reprisal attacks against Northern residents. Many participants in such reprisal attacks have been attracted to MASSOB's mobilization and reimagining of Biafra as the only safe haven for the Igbo.

The Igbo are not an exception. Violence is sometimes seen as the crucible of national consciousness. In fact, elites involved in ethnic mobilization often instigate violence to urge reluctant followers to the frontlines and moderates to jump off the fence (Fearon and Laitin 2000). The shedding of blood leads to a situation where groups begin to conceive of social differences in primordial terms. As Strassberg (1998) shows, the experience of the Holocaust and the transfer of its memories across generations largely accounts for why Jews everywhere emphasize their Jewish identity above national identities. However, African leaders, who in the anxiety to build the nation take to the bludgeoning of restive social groups, especially ethnic groups, have apparently forgotten this lesson. African national identities were often forged in the common experience of violence under colonial rule, and separatist ethnic nationalities are likely to be strengthened rather than overcome by current strategies of discrimination and violence (Fanon 1961). By forgetting too early the lessons of history, we risk repeating it as the passion for nation-building is paradoxically resulting in nation-destruction in Nigeria and beyond.

\section{Notes}

1. Ibeanu and Luckham (2006) have also observed the relative absence of nonviolence after the war.

2. See, for instance, 'Azikiwe Appeals to his Fellow-Easterners', in Kirk-Greene 1993: 422-6.

3. See Uche Nworah, 'The Igbo Leadership Crises', published on 20 March 2005 at http://www.nigeriavillagesquare1.com/Articles/Nworah/2005/03/leadershipcrises-in-igboland.html.

4. See Sunday Punch, 18 June 2006, pp. 8-10.

5. Saturday Punch, 24 June 2006, p. A12.

6. Vanguard, 5 November 2007, online edition.

7. For a good account of state repression of MASSOB, see Human Rights Watch 2005.

8. Human Rights Watch 2005.

9. A list of books on Biafra compiled by Dan Obi Awduche of the University of Massachusetts, Amherst is available at http://www.kwenu.com/igbo/ igbowebpages/Igbo.dir/Biafra/books_on_biafra.htm. 


\section{References}

Adichie, N. C., 2007, Half of A Yellow Sun, London: HarperCollins.

Agbaje, A., 2002, 'The War and the Nigerian State', in E. Osaghae, E. Onwudiwe and R. Suberu, eds, The Nigerian Civil War and its Aftermath, Ibadan: John Archers for Programme on Ethnic and Federal Studies, pp. 26-30.

Agbu, O., 2004, Ethnic Militias and the Threat to Democracy in Post-Transition Nigeria, Uppsala: Nordic African Institute.

Alli, C., 2001, The Federal Republic of Nigerian Army: The Siege of a Nation, Lagos: Malthouse Press.

Amaise, E., 2007, 'MASSOB: Woman Cries over Alleged Harassment', This Day, 12 June.

Anifowose, R., 1982, Violence and Politics in Nigeria: The Tiv and Yoruba Experience, New York: Nok Publishers.

Chuku, G., 2002, 'Biafra Women under Fire: Strategies in Organizing Local and Transborder Trade during the Nigeria Civil War', in E. Osaghae, E. Onwudiwe and R. Suberu, eds, The Nigerian Civil War and its Aftermath, Ibadan: John Archers for Programme on Ethnic and Federal Studies, pp. 216-28.

Collier, P., Hoeffler, A. and Rohner, D., 2006, Beyond Greed and Grievance: Feasibility and Civil War, Centre for the Study of African Economies, Working Paper Series 10.

Egwuonwu, A., 2004, 'New Strategies for a New War', Nigeria-Biafra War Memorial

Lecture, delivered on 29 May 2004; available at http://www.kwenu.com/biafra/ memorial2004/egwuonwu_lecture.htm.

Fanon, F., 1961, The Wretched of the Earth, Harmondsworth: Penguin.

Fearon, J. D. and Laitin, D. D., 2000, 'Violence and the Social Construction of Ethnic Identity’, International Organization 54(4):845-77.

Gboyega, A., 1997, 'Nigeria: Conflict Unresolved', in I. William Zartman, ed., Governance as Conflict Management: Politics and Violence in West Africa, Washington, DC: The Brookings Institution, pp. 149-96.

Hazen, J., 2007, Small Arms, Armed Violence and Insecurity in Nigeria: The Niger Delta Perspective, Small Arms Survey Occasional Paper 40, Geneva.

Human Rights Watch, 2005, 'Rest in Pieces': Police Torture and Custody Deaths in Nigeria, Vol. 17, No. 11(A), New York: Human Rights Watch.

Ibeanu, O. and Luckham, R., 2006, Niger Delta: Political Violence, Governance and Corporate Responsibility in a Petro-state, Lagos: CDD.

Igwe, D. and Awoyinfa, M., 2001, Orji Kalu: Leadership Lessons from a Master Strategist, Lagos: McDee Communications.

Kirk-Greene, A. H. M., 1993, Crisis and Conflict in Nigeria: A Documentary Sourcebook, 1966-1969, Vol. 1, London: Oxford University Press.

Lewis, P., 2007, Identity, Institutions and Democracy in Nigeria, AFROBAROMETER Working Paper 68.

Madiebo, A., 1981, The Nigerian Revolution and the Biafran War, Enugu: Fourth Dimension. 
Meagher, K., 2007, 'Hijacking Civil Society: The Inside Story of the Bakassi Boys Vigilante Group of South-Eastern Nigeria', Journal of Modern African Studies 45(1):89-115.

Mustapha, A. R., 2006, 'Ethnic Structure, Inequality and Governance of the Public Sector in Nigeria', in Y. Bangura, ed., Ethnic Inequalities and Public Sector Governance, Basingstoke: Palgrave Macmillan, pp. 159-77.

Obumselu, B., 2001, Massacre of Ndi Igbo in 1966: Report of the Justice G.C.M.

Onyiuke Tribunal, Lagos: Tolbrook (distributed by the Igbo Youth Movement).

Odion, L., 2000, ‘OPC versus Obasanjo', Thisday, 20 October.

Odumegwu-Ojukwu, E., 1989, Because I Am Involved, Ibadan: Spectrum Books.

Okocha, E., 1994, Blood on the Niger: An Untold Story of the Nigerian Civil War, Washington, DC; Lagos: USA Africa; GOM SLAM.

Omeje, K., 2005, 'Enyimba Enyi: The Come-back of Igbo Nationalism in Nigeria', Review of African Political Economy 32(103).

Osaghae, E., 1998, Crippled Giant: Nigeria Since Independence, London: Hurst. Shettima, K.A., 1997, 'Ecology, Identity, Developmentalism and Displacement in Northern Nigeria', in P. Lovejoy and P.A.T. Williams, eds, Displacement and the Politics of Violence in Nigeria, Leiden: Brill, pp. 67-80.

Strassberg, B., 1998, Talking Across Boundaries: Cultures of Violence, Culture of Peace, University of Notre Dame, IN: The John Kroe Institute for International Peace.

Stremlau, J., 1977, The International Politics of the Nigerian Civil War, 19671970, Princeton: Princeton University Press.

Ukiwo, U., 2003a, 'The Politicization of Bakassi Boys in Eastern Nigeria', in T. Babawale, ed., Ethnic Militia, Urban Violence and the Challenges of Democratic Consolidation in Nigeria, Lagos: Malthouse Press, pp. 130-51.

Ukiwo, U., 2003b, 'Politics, Ethno-religious Conflicts and Democratic Consolidation in Nigeria', The Journal of Modern African Studies 41(1):115-38.

Watts, M., 1999, 'Petro-violence: Some Thoughts on Community, Extraction and Political Ecology', Berkeley Workshops on Environmental Politics, available at http://repositories.cdlib.org/cgi/viewcontent.cgi?article=1000\&context=iis.

Williams, I., 2002, 'The Nigerian Civil War: A Lesson in Breakdown of Democratic Control of the Military and Military Professionalism', in E. Osaghae, E. Onwudiwe and R. Suberu, eds, The Nigerian Civil War and its Aftermath, Ibadan: John Archers for Programme on Ethnic and Federal Studies, pp. 100-13.

Williams, P. A. T., 1997, 'Religion, Violence and Displacement in Nigeria', in P. Lovejoy and P. A. T., Williams, eds, Displacement and the Politics of Violence in Nigeria, Leiden: Brill, pp. 33-49.

Zalik, A., 2004, “"Petro-violence” and "Partnership Development”, Review of African Political Economy 31(101):401-24. 